\title{
Correction to: Conducting a Time Trade-Off Study Alongside a Clinical Trial: A Case Study and Recommendations
}

\author{
Jing Shen ${ }^{1}(1) \cdot$ Sarah Hill ${ }^{1}$. David Mott ${ }^{1,2} \cdot$ Matthew Breckons $^{1} \cdot$ Luke Vale $^{1} \cdot$ Rob Pickard $^{3}$
}

Published online: 23 May 2019

(c) The Author(s) 2019

\section{Correction to: PharmacoEconomics Open (2019) 3:5-20 https://doi.org/10.1007/s41669-018-0084-1}

The Open Access license, which previously read:

Open Access This article is distributed under the terms of the Creative Commons Attribution-NonCommercial 4.0 International License (http://creativecommons.org/licenses/ by-nc/4.0/), which permits any noncommercial use, distribution, and reproduction in any medium, provided you give appropriate credit to the original author(s) and the source, provide a link to the Creative Commons license, and indicate if changes were made.

Should read:

Open Access This article is distributed under the terms of the Creative Commons Attribution 4.0 International License (http://creativecommons.org/licenses/by/4.0/), which permits unrestricted use, distribution, and reproduction in any medium, provided you give appropriate credit to the original author(s) and the source, provide a link to the Creative Commons license, and indicate if changes were made.

The original article can be found online at https://doi.org/10.1007/ s41669-018-0084-1.

Jing Shen

jing.shen@newcastle.ac.uk

1 Health Economics Group, Institute of Health and Society, Newcastle University, Newcastle, UK

2 Office of Health Economics, London, UK

3 Institute of Cellular Medicine, Newcastle University, Newcastle, UK
The original article has been corrected.

Open Access This article is distributed under the terms of the Creative Commons Attribution 4.0 International License (http://creativecommons.org/licenses/by/4.0/), which permits unrestricted use, distribution, and reproduction in any medium, provided you give appropriate credit to the original author(s) and the source, provide a link to the Creative Commons license, and indicate if changes were made. 